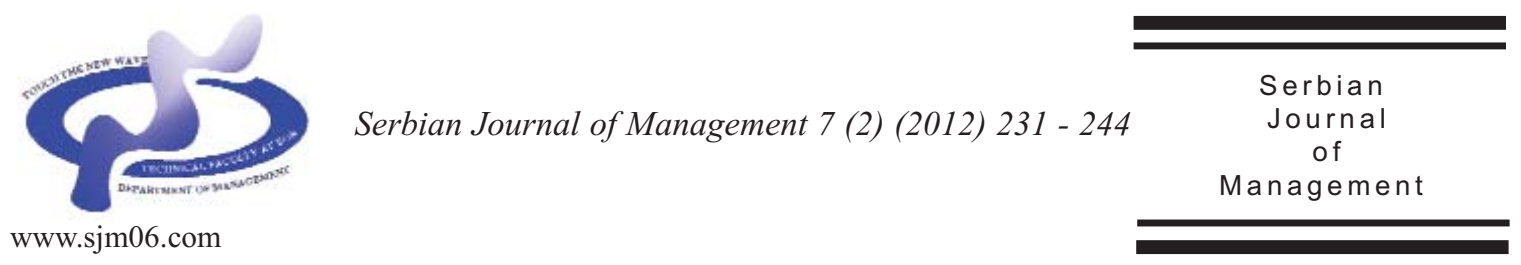

\title{
A COMPARATIVE STUDY ON CONSERVATISM USING BASU'S AND BALL \& SHIVAKUMAR'S METHODS
}

\author{
Bizhan Abedini ${ }^{\mathrm{a}}$ and Mahdi Salehi ${ }^{\mathrm{b}}{ }^{*}$

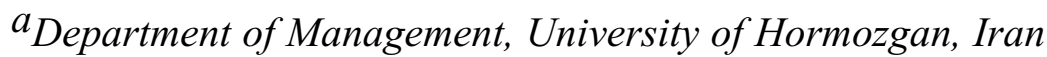

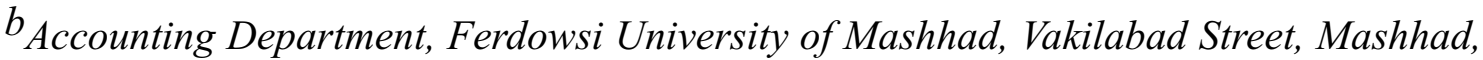 \\ Postal code 9177948974, Iran
}

\begin{abstract}
The current study aims to investigate the relationship between conservatism of profit and the ratio of the market value to book value with Basu's and Ball \& Shivakumar's methods in Iran. For this purpose, 155 listed companies in Tehran Stock Exchange consider as sample of the study during 2004-2010. In this context, it is used two methods (Basu and Ball \& Shivakumar's Models) to measure conservatism of profit. According to calculations and using regression, the obtained results shows that there is no significant relation between conservatism of profit and the ratio of the market value to book value in both employed methods of conservatism.
\end{abstract}

Keywords: conservatism of profit, ratio of the market value to book value, good news, Basu's method, Ball \& Shivakumar's method

\section{INTRODUCTION}

Historical records from early $15^{\text {th }}$ century trading partnerships show that accounting in medieval Europe was conservative. Accounting conservatism defined by the adage "anticipates no profit, but anticipates all losses" (Bliss, 1924). Anticipating profits means recognizing profits before there is a verifiable legal claim to the revenues generating those profits. Conservatism does not imply that all revenue cash flows should be received before profits are recognized.

The support of any conscious decision is the information obtained in the field about which the decision is made if the information does not reflect the realties, and then it will have bad effects on the decisions made by

\footnotetext{
* Corresponding author: mahdi_salehi54@yahoo.com
}

DOI: $10.5937 /$ sjm 7-1367 
their users (Namazi \& Salehi, 2010). Therefore, in order to protect the rights of the users some references are needed for monitoring the activities of information providers and using control mechanisms related to the subject to reduce false decisions. Therefore, accountants have used conservatism as one of the limiting principles of accounting for many years. Sterling (1970) rates conservatism as the most influential principle of valuation in accounting. Conservatism is an important attribute of high quality reporting.

Basu (1997) argues that conservatism has influenced accounting practice for at least five hundred years. Ahmed (2007) argues that accounting conservatism can help reducing agency costs of firms.

It is often used to assess the quality of companies accounting reports. The current study aims to examine the relationship between conservatism of profit and the ratio of the market value to book value with Basu's and Ball \& Shivakumar's methods in Iran.

\subsection{Research problem}

Conservatism procedures are considered as an effective factor on financial activates and decision-making. This subject is based on reasoning that the procedures' selected by management will affect its performance (Moradi \& Salehi, 2011). According to the concept of conservatism, accounting should report on one hand the lowest value for the assets and revenues and on the other hand, the most possible value for debt and expenses. Accounting must also identify expenses and revenues as early as possible and as late as possible, respectively. Thus, net assets will be less than the current price leading to the selection of minimum amount of available funds hence the interpretation of financial reports information according to the conservative procedures will be difficult even for the most skillful users. Profit because of accounting process and the main source of information, which is important for the users of accounting information, may be influenced by accounting practices, selected by the measurement management.

According to Salehi et al., (2011), by using uniform and conservative accounting practices can make a high profit quality while in their opinion changes in accounting principles and estimates and the lack of using a conservative approach will leads to a low profit quality; conservatism in financial reporting is due to some economic reasons, four of which are as follows:

(1) Contractual factor;

(2) Legal claims;

(3) Taxes; and

(4) Accounting rules and regulations.

The current study aims to compare different models. The expected conservatism of investors as well as the relationship between the ratio of market value to book value and the conservatism of listed companies in Tehran Stock Exchange (TSE) will be examined. The study assumes that the conservatism of profit or the tendency to recognize bad news about benefits rather than good news is basically more considerable, In the portfolio of the firms with lower ratios of market value to book value, and ultimately compares the relation between the conservatism of profit and the ratio of market value to book value according to the Basu's method with the Ball \& Shivakumar's method.

Assuming the equity return of the stocks owners in this year maintains the good and bad news about the expected future cash flows of companies, this leads to the 
assumption that a coefficient of deviation in a regression of efficiency profit of companies with negative returns will be higher than companies with positive returns (negative returns of companies is bad news and positive returns of companies is good news).

\subsection{Importance of the study}

One of the most important concepts in the assessment and analysis of financial statements is the concept of conservatism.

Therefore, understanding the factors that influence on conservatism helps to investor in line with correct management of asset selection with more conservatism and avoidance of representing unrealistic statements.

This study investigated factors related to conservatism of companies such as the ratio of market value to the book value.

Because of the numerous users and diversity in their awareness levels of the financial terms, there is not any possibility of providing the conditions for releasing nonprocessed documents and information resources. Hence, the role of accounting as a converter and producer of useful information and these stockholders is a necessity. Because of the lack of direct, access of all users to the information resources for economic timeliness and optimized decisions these information's which provided through financial reports must have features that project the rights of the users. Conservatism is one of the features of financial reporting which is in the form of a limiting principle in the frame work of accounting principles, plays an important role in limiting the optimistic behaviors of managers in the position of information suppliers on one hand and impose a minimum estimate of investment income by investors and creditors as the most important users, on the other hand. Considering the literature and previous researches based on conservatism, the importance of this accounting measure is obvious indifferent fields such as solving the problems arising from representation neutralizing the problems caused by information asymmetry between aware and unaware uses giving the rights of major stockholders, positive impact on reducing borrowing costs and capital costs and increasing financial leverage, the role of deterrence against the occurrence of financial scandals and undeniable role in steering the company and so on. There are of course some true criticisms of conservatism, and the providers of standards must consider all of the positive and negative aspects of conservatism and its expenses and benefits. Some of the criticism is that the offering of the value of an asset under its real value leads to express more earning than actual one. The conservatism is also opposite to the important qualitative features such as an honest expression, neutrality and comparability (including stable procedure).

\subsection{Research objectives}

1 - Comparison of the relationship between conservatism of profit and the ratio of market value to book value according to the Basu's and Ball \& Shivakumr's methods.

2 - Comparison of the relationship between conservatism of profit and selected portfolios according to the Basu's and Ball \& Shivakumar's methods.

3 - Comparison of the relationship between conservatism of profit and courses tested according to the Basu's and Ball \& Shivakumar's methods. 


\section{LITERATURE REVIEW}

Basu (1997) in the estimation of conservatism index studied the relationship between earnings and returns of stocks through the regression. He found that in the companies with negative stock returns, there is greater correlation between stock return and income, with respect to the companies with positive stock returns. He also found that during the increased judicial proceeding in the USA, the conservatism has increased too.

Givoly and Hayn (2000) showed in a study that in the USA in the past four decades, the income has declined, but this decrease does not lead to the reduced cash flows. In addition, profit distribution is very scattered. Results of their investigations point out that recognition of bad news are sooner than recognition of good news and the degree of conservatism in financial reporting in the USA has increased.

Beaver and Ryan (2000) studied the relationship between conservatism with depreciation expense, research and development, advertising cost and storage of reduced value of inventory. They found in the study that the depreciation expense according to descending method the cost of research and development and advertising cost have negative effects on conservatism, but the index of storage of reduced value of inventory has positive effect on conservatism.

Watts (2001) found that there was conservatism before standardization but during the rule of financial accounting standards board had increased its rate.

Penman and Zhang (2002) show that conservatism accounting procedures; increase the cost of capital spending this could reduce profits and create hide reserves.
As a result, the quality of earnings due to conservatism is reduced.

Ahmed's et al. (2002) reached the conclusion that, conservatism accounting, prevents managers invest in projects with negative returns. In addition, there is a direct relationship between the percentage of shares reserved by board members and conservatism.

Lobo (2008) in the research that whether the growth of a business unit is one of the components of conservatism in finantial reporting and by using an adjusted model based on Basu's model found that the amount of conservatism in business units with lower growth is higher than business units with higher growth.

Mozafar (2009) studied the measurements of conservatism components as quantitative criteria. He found that the business units with more long-term investments and offer opaque information have more conservatism. In addition, the increase in accounting conservatism causes the inequality of information and less validity of business units.

Wang (2009) suggested a new theory about the economic demand for accounting conservatism, which pointed out the prominent role of accounting conservatism, through the disparity of information in the debt market.

Banimahd (2006) offered a model for measuring conservatism in the affiliated companies in Tehran stock exchange and concluded that conservatism is reduced due to reducing efficiency of assets and cash returns (ratio of operating cash flow to total assets) and is decreased due to increasing long term debts the growth of companies operations.

Sadidi (2008) found that there is a positive relationship between accounting 
conservatism and earning quality and there is very low significant verse relationship between saving tax and accounting conservatism and there is not any significant relationship between accounting conservatism and between conservatism and the company size.

Rezazadeh (2002) focus to determine relationship between information asymmetry among investors and the amount of conservatism in financial reporting found that, there is a significant positive relationship between information asymmetry among investors and the level of conservatism applied in the financial statements.

Salehi, Ghorbani and Jafarian (2011) studied the conservatism in Iran based on Ball \& Shivakumar's Model. The results of the study show that there is no meaningful relationship between profit conservatism and the ration of market value to the book value in companies listed in TSE.

\section{RESEARCH METHODOLOGY}

This research is trying to use the information provided in the financial statements of the companies listed in TSE to determine the effect of accounting conservatism on the market value to book value ratio.

The temporal scope of the research from 2004 to 2010 has been established for different financial periods because of the limitations in collecting information. Reasons for its selection are:

1- There is more information and data about the listed companies during the mentioned years in the Tehran stock exchange.

2- The more observations lead to more validity of research results.

Considering the above data, the data of the studied companies was selected for a period of 7 years.

This research is a solidarity and harmony study and is at the field of descriptive studies the required data of which will be collected from the real information of listed companies in TSE.

Testing of hypotheses and collecting of data will be done by using appropriate equations and OLS and so on.

In order to collect relevant data we have used the database of Tadbir pardaz software.

The desired research is an applied one and the models of testing the research hypotheses are multivariate and univariate linear regression models.

\section{Measuring conservatism:}

Measuring of earning conservatism is the result of sampling and reverse regression of earnings efficiency in portfolio of companies. Method of measurement is the method of Basu. Because this compare to other models of measuring conservatism this model has high validity. In order to obtaining comparative results, it is also employed Ball \& Shivakumar's Model. Therefore, the current study will measure the conservatism based on two methods that it is given by equation (1).

$$
\left(X_{i t}=\beta_{o t}+\beta_{1 t} R_{1 t}+\varepsilon_{i t}\right)
$$

Where:

$\mathrm{x}_{\mathrm{it}}$ is the variable of company's profit for the financial year $t$, which is balanced through the market value of equity at the beginning of financial year (i.e. the end of financial year $\mathrm{t}-1$ ).

$\mathrm{R}_{\mathrm{it}}$ is a variable showing the market return rate of stock $i$ of the company for 12 month that will end 4 month after the next 
fiscal year. $\varepsilon_{i t}$ represents randomized intervention the regression coefficient.

$\beta_{\text {it }}$ is interpreted as a measure of timeliness by which, the profits reflect the annual yield in a portfolio of companies the fiscal years of which will be end during the year $t$ to within a certain portfolio of companies.

It is estimated $\left(\beta_{1 t}\right)^{G N}$ and $\left(\beta_{1 t}\right)^{B N}$ for sub portfolios of companies with good and bad news in the year $t$.

The measurement of earning conservatism is for a certain portfolio $C_{t}^{P}=\beta_{1}^{B N(p)}-\beta_{1}^{G N(p)} \quad$ is the difference in high sensitivity of profit to bad news versus good news of companies in the portfolio $p$ during the fiscal year $t$.

The measurement of market value to book value ratio in the beginning of the year $p_{t-1} / B_{t-1}$ where $P_{t-1}\left(B_{t-1}\right)$ shows the market value (book value) of equity at the end of fiscal year $\mathrm{t}-1$.

For measuring conservatism, we can also use Ball and Shivakumar's methods (2005) which it is given by equation (2):

Accit $=\alpha 0+\alpha 1$ DCFO it $+\alpha 2$ CFOit $+\alpha 3$ CFOit *DCFOit

Where:

Accit: is operating income for the company i minus operating cash flow in year $\mathrm{t}$, which has been balanced by the total assets in the year $\mathrm{t}-1$.

DCFOit: is 1 for negative operating cash flow in the year $t$ and is zero for other cases.

CFOit: is the operating cash flows for companies in the year $\mathrm{t}$ divided by total assets at year $\mathrm{t}-1$.

$\alpha 3$ : is the earning conservatism.

Ball and Shivakumar (2005) predicted a positive for the earning conservatism; the higher $\alpha 3$ will lead to higher earning conservatism.

\subsection{Research hypotheses}

According to the purpose of the study, the following hypotheses are postulated in the study:

1- Earning conservatism is higher in portfolios with lower market value to book value ratio.

2- There is earning conservatism in all portfolios.

3- There is earning conservatism in all tested periods.

\subsection{Research's variables}

Dependent variable in this study according to the Basu's method is earning conservatism which obtained by the difference between high sensitivity of profit in companies for bad news against good news.

According to the Ball and Shivakumar's (2005) method, the dependent variable is earning conservatism, which is measured by company's operational income minus operating cash flows in the year $t$ balanced by the total assets in the year $\mathrm{t}-1$.

\subsection{Independent variables related to the model of measuring conservatism}

1- The sensivity of profit for bad news.

2- The sensitivity of profit to good news.

3- Operating cash flow for companies in the year $t$ divided by the total assets at the year $\mathrm{t}-1$.

4- Imaginary (virtual) variable: if operating cash flows for the year $i$ is negative in the year $t$, then it will be equal to 1 , 
otherwise will be 0 .

\subsection{Statistical society}

The statistical society of the present research is listed companies in TSE; this sample includes companies that have the following conditions.

-Companies have listed in TSE from the beginning of 2003 or before.

-The companies are not active in the financial brokerage industry.

- Fiscal year is not changed.

- Companies with accessible data.

- Multi-industry companies are excluded.

- Corporate financial year ending is the end of March each year.

- Interdisciplinary industrial companies are excluded by considering 6 conditions mentioned above, there were 302 qualified companies for statistical society.

Among all of the listed companies in TSE 155 companies are selected.

Now the question is whether the results of this, research of 155 companies can be generalized to the completely listed companies in TSE (statistical society) or not?

We can answer that with regard to the size of the statistical society, the distribution of the society is normal and we can calculate the sample size which given by equation (3):

$$
n=\frac{\left[Z_{\frac{\alpha}{2}}\right]^{2} \times p \times q \times N}{(N-1) \times \epsilon^{2}+\left[\left(Z_{\frac{\alpha}{2}}\right)^{2} \times p \times q\right]}
$$

Where:

$\mathrm{N}$ : is the size of the statistical society.

$\mathrm{n}$ : is the sample size.

$\mathrm{p}$ : is the success ratio.

$\mathrm{q}$ : is the failure ratio.

$\mathrm{z}$ : is the variable of normal distribution standard.

$\mathrm{e}:$ is the estimation error.

In this study, the estimation error equals to $6 \%$ and the confidence interval is 95 percent and initial estimates for confirming hypothesis by observations is equal to 0.5 also given that the listed companies in TSE and satisfied the five conditions mentioned above, were 302 companies, the size of the sample can be calculated by equation (4).

$$
\begin{aligned}
& \mathrm{n}=\frac{(1.96)^{2} \times 0.5 \times 0.5 \times 302}{301 \times(\% 6)^{2}+\left[(1.96)^{2} \times 0.5 \times 0.5\right]}=142 \\
& \mathrm{p}=0.5 \quad \mathrm{q}=0.5 \\
& \mathrm{Z}_{\frac{\alpha}{2}}=\mathrm{Z}_{\% 25}=1.96 \quad \mathrm{~N}=302
\end{aligned}
$$

Thus, it is seen that at the $95 \%$ confidence level and error equal to $6 \%$ we must choose at least 142 samples to generalize the results for statistical society. Since in the current research we have studied 155 companies, the results of the statistical sample can be generalized to the whole companies listed in TSE for the examined.

\subsection{Data collection}

For data collection, resources and magazines in the libraries and recourses available in domestic and international magazines are selected as references.

Information and data needed are collected through software and through financial statements of companies in the compact discs (CD) published by the TSE and the companies web sites.

For data analysis the deviation regression coefficient and SPSS software, are used deviation regression coefficient is the relationship between earning conservatism and the ratio of market value to the book 
value.

Statistical sample is divided into two groups. The first group is the common stock with positive returns (good news) and the second group is the common stock with negative return (bad news). The Pearson's correlation coefficient is employed for statistical test the companies with the ratios of $\mathrm{P} / \mathrm{B}$ less than one are divided into 2 equal sizes in the first portfolio, and the companies with ratios of $\mathrm{P} / \mathrm{B}$ greater than one are divided into equal sizes in the remained portfolios (3 to 5). The ratio of $\mathrm{P} / \mathrm{B}$ equals to 1 maybe a critical level that will stimulate the implementation of conservatism. The portfolio 1 includes companies with lowest ratios of $\mathrm{P} / \mathrm{B}$ and portfolio 5 includes companies with the highest ratios of $\mathrm{P} / \mathrm{B}$. To determine the exact effect of observations, the middle means is used, that is the highest and lowest percentages of dividends and market to book ratios are deleted.The observations with the negative equity book are deleted at the beginning of financial year.

\section{EXPERIMENTAL RESULTS}

According to the Basu's method, the variable Xit in the equation (5) as following:

$$
X_{i t}=\beta_{o t}+\beta_{1 t} R_{1 t}+\varepsilon_{i t}
$$

Is the company profit for the financial year $t$ balanced through market value of equity at the beginning of financial year (or the end of the financial year $t-1$ ). The variable Rit shows the rate of return of stock i for the 12 months ended four months after the end of next fiscal year and $\varepsilon_{i t}$ is the randomized intervention. $\beta_{1}$ and $\beta_{2}$ are good news and bad news respectively showing the estimation of stock returns in the sub samples of good and bad news in the $\mathrm{P} / \mathrm{B}$ portfolios. The earning conservatism is measured according to equation (6):

$$
C_{t}^{P}=\beta_{1}^{B N(p)}-\beta_{1}^{G N(p)}
$$

Alternatively, difference between the coefficient of deviation for companies with good news and bad news $\left(\beta_{\mathrm{it}}\right)$ in a particular portfolio is interpreted as a measure of accuracy in time.

\section{Ball and Shivakumar's method (2005):}

In the regression equation (7):

$$
\text { Accit }=\alpha 0+\alpha \text { 1DCFO it }+\alpha 2 \text { CFOit }+\alpha 3
$$
CFOit *DCFOi

The variable accit represents operational revenue for the company $\mathrm{i}$ minus current operating cash flows in the year $t$, which is balanced by the total assets in the year $\mathrm{t}-1$.

The variable DCFOit is 1 , if the operating cash flows for company $i$ in the year $t$, is negative, otherwise it will be zero. The variable CFOit represents operating cash flows of companies in the year $t$ divided by total assets at the year $\mathrm{t}-1 . \alpha 3$ represents the earning conservatism.

Ball and Shivakumar (2005) predicted a positive coefficient $\alpha 3$ for the earning conservatism, the greater $\alpha 3$ leads to the higher earning conservatism. Table shows the descriptive statistics of the whole sample. Tables 1, 2, and 3 show the general information of the full sample of the study.

Table 4 represents the results of the study according to the Basu's model. 
Table 1. Descriptive statistics full sample

\begin{tabular}{|c|c|c|c|c|c|c|c|}
\hline Variable & Mean & S.D & $\begin{array}{c}\text { First } \\
\text { Quartile }\end{array}$ & Median & $\begin{array}{c}\text { Third } \\
\text { Quartile }\end{array}$ & Min & Max \\
\hline R & 0.232 & 0.821 & -0.128 & 0.022 & 0.349 & -1.240 & 7.160 \\
\hline E & 0.183 & 0.752 & 0.027 & 0.121 & 0.214 & -5.204 & 9.610 \\
\hline P/B & 6.883 & 108.50 & 0.000 & 1.525 & 3.740 & 0.000 & 50.330 \\
\hline Accit & 0.116 & 0.2007 & 0.009 & 0.091 & 0.202 & -1.260 & 1.390 \\
\hline Cfoit & 0.115 & 0.2007 & 0.009 & 0.091 & 0.201 & -1.260 & 1.390 \\
\hline
\end{tabular}

Table 2. Descriptive statistics full sample about good news

\begin{tabular}{|c|c|c|c|c|c|c|c|}
\hline Variable & Mean & $\begin{array}{c}\text { Standard } \\
\text { Deviation }\end{array}$ & $\begin{array}{c}\text { First } \\
\text { Quartile }\end{array}$ & Median & $\begin{array}{c}\text { Third } \\
\text { Quartile }\end{array}$ & Min & Max \\
\hline R & 0.617 & 0.953 & 0.127 & 0.314 & 0.638 & 0.001 & 7.163 \\
\hline E & 0.292 & 0.716 & 0.080 & 0.163 & 0.273 & -3.500 & 6.680 \\
\hline P/B & 10.060 & 1.480 & 0.000 & 1.677 & 4.090 & 0.000 & 50.33 \\
\hline Accit & 0.148 & 0.202 & 0.028 & 0.122 & 0.230 & -0.734 & 1.394 \\
\hline Cfoit & 0.148 & 0.202 & 0.028 & 0.122 & 0.230 & -0.734 & 1.394 \\
\hline
\end{tabular}

Table 3. Descriptive statistics full sample about bad news

\begin{tabular}{|c|c|c|c|c|c|c|c|}
\hline Variable & Mean & S.D & $\begin{array}{c}\text { First } \\
\text { Quartile }\end{array}$ & Median & $\begin{array}{c}\text { Third } \\
\text { Quartile }\end{array}$ & Min & Max \\
\hline R & -0.262 & 0.206 & -0.401 & -0.226 & -0.085 & -1.24 & -0.0003 \\
\hline E & 0.137 & 0.773 & 0.024 & 0.090 & 0.169 & -2.589 & 9.609 \\
\hline P/B & 3.995 & 8.179 & 0.000 & 1.940 & 4.270 & 0.000 & 110 \\
\hline Accit & 0.098 & 0.186 & 0.012 & 0.086 & 0.195 & -1.260 & 0.713 \\
\hline cfoit & 0.098 & 0.186 & 0.012 & 0.086 & 0.195 & -1.260 & 0.713 \\
\hline
\end{tabular}

Table 4. Relationship between earnings and returns in each year according to the Basu's

\begin{tabular}{|c|c|c|c|c|c|c|c|c|c|}
\hline \multirow[b]{2}{*}{ Year } & \multicolumn{4}{|c|}{ Good News } & \multicolumn{4}{|c|}{ Bad News } & \multirow[b]{2}{*}{$\beta_{1}^{B N(P)}-\beta_{1}^{G N(P}$} \\
\hline & No & $\beta_{0}$ & $\beta_{1}$ & $\begin{array}{c}\text { Adjusted } \\
\text { R1 }\end{array}$ & No & $\beta_{0}$ & $\beta_{1}$ & $\begin{array}{c}\text { Adjusted } \\
\text { R2 }\end{array}$ & \\
\hline 2004 & 93 & 0.090 & 0.183 & 0.063 & 52 & 0.13 & 0.120 & 0.001 & 0.056 \\
\hline 2005 & 96 & 0.132 & 0.030 & 0.010 & 53 & 0.106 & 0.291 & 0.005 & 0.261 \\
\hline 2006 & 86 & 0.120 & -0.037 & -0.008 & 55 & 0.055 & 0.124 & 0.004 & 0.162 \\
\hline 2007 & 63 & 0.184 & -0.045 & 0.028 & 77 & 0.118 & 0.251 & 0.022 & 0.296 \\
\hline 2008 & 71 & 0.553 & 0.534 & 0.025 & 50 & 0.582 & -0.080 & -0.021 & -0.614 \\
\hline 2009 & 81 & 0.974 & -0.250 & -0.003 & 31 & 0.340 & 0.555 & 0.284 & 0.805 \\
\hline 2010 & 60 & 0.171 & -0.011 & -0.017 & 65 & 0.052 & -0.03 & -0.015 & -0.020 \\
\hline Mean & & 0.318 & 0.058 & 0.014 & & 0.198 & 0.176 & -0.006 & 0.118 \\
\hline
\end{tabular}

As it can be seen in the years 2004, 2005, conservatism is for the year 2009 and the 2006, 2007 and 2009 earning conservatism lowest one is for the year 2008.

exists but in the years 2008 and 2010 there Table 5 portrays the results of the study was not earning conservatism. according to the Ball and Shivakumar's

The highest value of the earning method. 
Table 5. Relationship between earnings and returns in each year, according to the Ball and Shivakumar's method

\begin{tabular}{|c|c|c|c|c|c|}
\hline Year & No. & $\alpha_{0}$ & $\alpha_{1}$ & $\alpha_{2}$ & $\alpha_{3}$ \\
\hline 2004 & 145 & -0.011 & 0.011 & 1 & 0.048 \\
\hline 2005 & 149 & 0.000 & 0.000 & 1 & 0.000 \\
\hline 2006 & 141 & 0.173 & -0.170 & 1 & 0.490 \\
\hline 2007 & 143 & 0.250 & 0.780 & 1 & 0.110 \\
\hline 2008 & 121 & 0.164 & -0.160 & 1 & -0.256 \\
\hline 2009 & 122 & -0.360 & 0.377 & 1 & 0.689 \\
\hline 2010 & 125 & 0.250 & -0.250 & 1 & 0.320 \\
\hline
\end{tabular}

As can be seen in the years 2009, 2004, 2006, 2007 and 2010 earning conservatism exists, but in the years 2005 and 2008 there was not earning conservatism. The highest earning conservatism is related to the year 2009 and the least amount of earning conservatism is related to the year 2008 .

Table 6 presents the relation of earnings and returns according to the Basu's as well Ball and Shivakumar's methods.

Table 6. Relationship between earnings and returns in each year, according to both methods

\begin{tabular}{|c|c|c|}
\hline Year & $\beta_{1}{ }^{B N(P)}-\beta_{1}{ }^{G N(P}$ & $\alpha_{3}$ \\
\hline 2004 & 0.056 & 0.048 \\
\hline 2005 & 0.261 & 0.000 \\
\hline 2006 & 0.162 & 0.490 \\
\hline 2007 & 0.296 & 0.110 \\
\hline 2008 & -0.614 & -0.256 \\
\hline 2009 & 0.805 & 0.689 \\
\hline 2010 & -0.020 & 0.320 \\
\hline
\end{tabular}

As can seen according to the method of base in the years 2004, 2006, 2008, 2005, and 2009 earning conservatism exists, but in the years 2008 and 2010 there was not earning conservatism.

However, according to the Balls and Shivakumar (2005) there exist earning conservatism in the years 2009, 2004, 2006, 2008 and 2010 but there was not earning conservatism in the years 2005 and 2008. In both methods, the highest earning conservatism is related to the year 2009 and the lowest one is related to the year 2008 .

As can be seen in the portfolios 1, 2, 3 and 4 there is earning conservatism, but in the portfolio 5 there is not earning conservatism (The portfolio 5 has the highest $\mathrm{P} / \mathrm{B}$ ratio).

In addition, it is observed that there is not any significant relation between earning conservatism and the $\mathrm{P} / \mathrm{B}$ ratio. The highest earning conservatism is related to the Table 7. Relationship between earnings and returns in each portfolio according to the Basu's method

\begin{tabular}{|c|c|c|c|c|c|c|c|c|c|}
\hline \multirow{2}{*}{ Variable } & \multirow{2}{*}{$\mathrm{P} / \mathrm{B}$} & \multicolumn{3}{|c|}{ Good News (GN) } & \multicolumn{3}{|c|}{ Bad News (BN) } & \multirow{2}{*}{$\begin{array}{c}C^{D}= \\
\beta_{1}^{B N\left(P^{\prime}\right)}-\beta_{1}^{\text {ciN }(P)}\end{array}$} & \multirow{2}{*}{$\begin{array}{c}\mathrm{CP} \\
\mathrm{CP}+1\end{array}$} \\
\hline & & $\beta_{0}$ & $\beta_{1}$ & Adj. R2 & $\beta_{0}$ & $\beta_{1}$ & Adj.R2 & & \\
\hline \multirow{5}{*}{$\begin{array}{l}\text { Mean of } \\
\text { Annual } \\
\text { regressions } \\
\text { (t-value) }\end{array}$} & $\begin{array}{c}\text { V } \\
\text { (high) }\end{array}$ & 0.222 & -0.034 & -0.012 & 0.072 & -0.065 & -0.028 & -0.031 & \\
\hline & IV & 0.370 & -0.102 & -0.002 & 0.304 & 0.432 & 0.000 & 0.534 & 0.503 \\
\hline & III & 0.255 & 0.025 & -0.003 & 0.195 & 0.248 & 0.004 & 0.223 & 0.726 \\
\hline & II & 0.345 & 0.067 & -0.007 & 0.193 & 0.211 & -0.023 & 0.144 & 0.87 \\
\hline & $\begin{array}{c}1 \\
\text { (low) }\end{array}$ & 0.261 & 0.108 & 0.000 & 0.276 & 0.491 & 0.001 & 0.383 & 1.253 \\
\hline \multicolumn{2}{|c|}{$\beta_{1}^{P / B(1)}-\beta_{1}^{m / B(V)}$} & & 0.142 & & & 0.556 & & 0.414 & \\
\hline
\end{tabular}


portfolio 4 and the lowest one is related to the portfolio 5 .

Table 8 portrays the relation between earnings and returns in each portfolio according to the Ball and Shivakumar's method.
Table 9 presents the relationship between earnings and returns in each portfolio according to both methods.

As can be seen, in both methods in the portfolios 1, 2, 3 and 4 there is earning conservatism but in the portfolio 5 there is

Table 8. Relation between earnings and returns in each portfolio according to the Ball and Shivakumar's method

\begin{tabular}{|c|c|c|c|c|c|}
\hline Test & $\begin{array}{c}\mathrm{P} / \mathrm{B} \\
\text { Portfolio }\end{array}$ & $\alpha_{0}$ & $\alpha_{1}$ & $\alpha_{2}$ & $\alpha_{3}$ \\
\hline \multirow{5}{*}{$\begin{array}{c}\text { Mean of Annual regressions } \\
\text { (t-value) }\end{array}$} & $\begin{array}{c}\mathrm{V} \\
\text { (high) }\end{array}$ & 0 & 0 & 1 & 0 \\
\hline & IV & -0.002 & 0.0902 & 1 & 0.192 \\
\hline & III & 0.233 & -0.233 & 1 & 0.022 \\
\hline & II & 0.037 & -0.037 & 1 & 0.144 \\
\hline & $\begin{array}{c}\mathrm{I} \\
\text { (low) }\end{array}$ & 0.189 & -0.164 & 1 & 0.079 \\
\hline
\end{tabular}

As can be seen in the portfolios 1, 2, 3 and 4 there is earning conservatism, but in the portfolios there is not earning conservatism (The portfolio 5 has the highest $\mathrm{P} / \mathrm{B}$ ratio).

In addition, it can be seen that there is not any significant relation between the earning conservatism and the $\mathrm{P} / \mathrm{B}$ ratio. The highest earning conservatism is related to the portfolio 4 and the lowest one is related to the portfolio 5 . not earning conservatism.

Also in both methods, there is not any significant relation between the earning conservatism and $\mathrm{P} / \mathrm{B}$ ratio. In both methods, the highest earning conservatism is related to the portfolio 4 and the lowest one is related to the portfolio 5 .

Figure 1 represents the fluctuation of earnings conservatism per year.

Table 9. Relationship between earnings and returns in each portfolio according to both methods

\begin{tabular}{|c|c|c|}
\hline Variable & Method of Basu (1) & $\begin{array}{c}\text { Method of Ball \& } \\
\text { Shivakumar (2) }\end{array}$ \\
\hline $\begin{array}{c}\text { P/B } \\
\text { Portfolio }\end{array}$ & $\beta_{1}^{B N(P)}-\beta_{1}^{G N(P}$ & $\alpha_{3}$ \\
\hline V (high) & -0.031 & 0.000 \\
\hline IV & 0.534 & 0.192 \\
\hline III & 0.223 & 0.022 \\
\hline II & 0.144 & 0.144 \\
\hline I & 0.383 & 0.079 \\
\hline
\end{tabular}




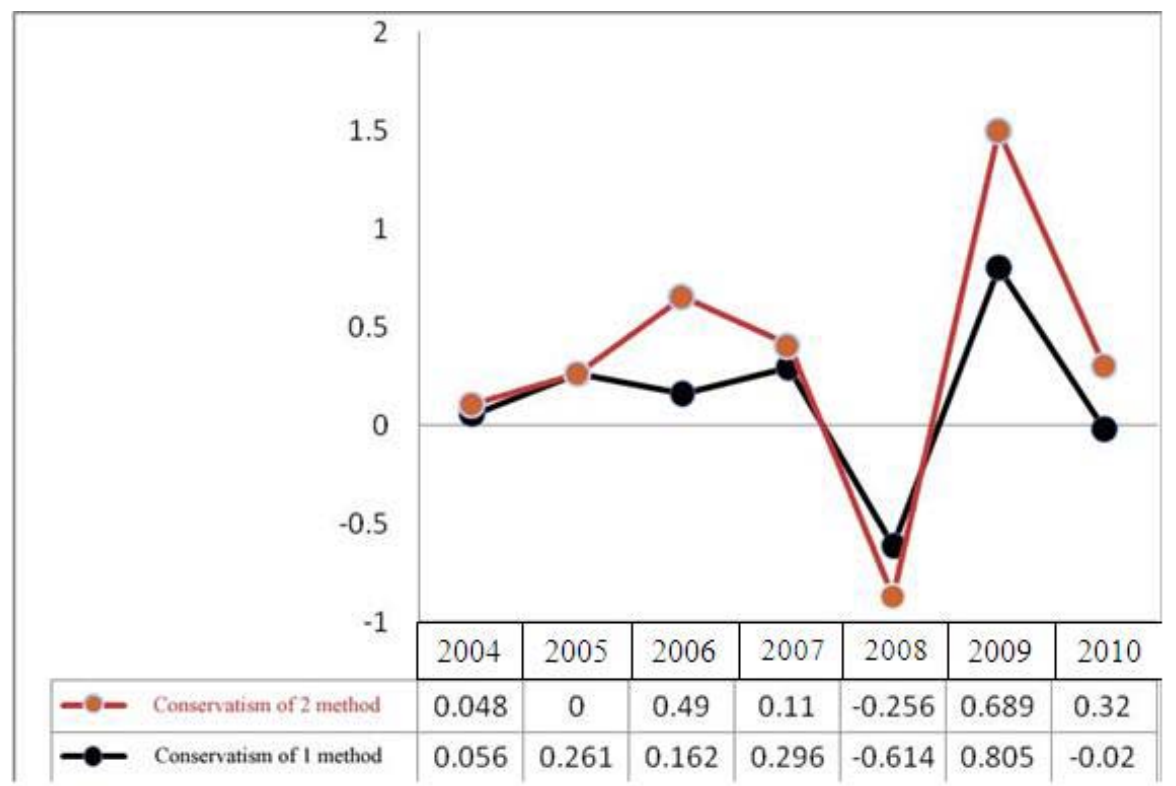

Figure 1. Increase and reduction of the earning conservatism per year

Figure 2 portrays the fluctuation of their use in contracts, if the measures are conservatism in each portfolio. useful to investors and so affect management's welfare. According to the calculations, there is not any relationship

\section{CONCLUSION} between earning conservatism and the ratio of market value to the book value. Also there

Conservatism addresses problems in is not earning conservatism in all of the financial reporting earnings and asset portfolios and tested periods then all of the measures that still exist in the absence of hypotheses are refuted.

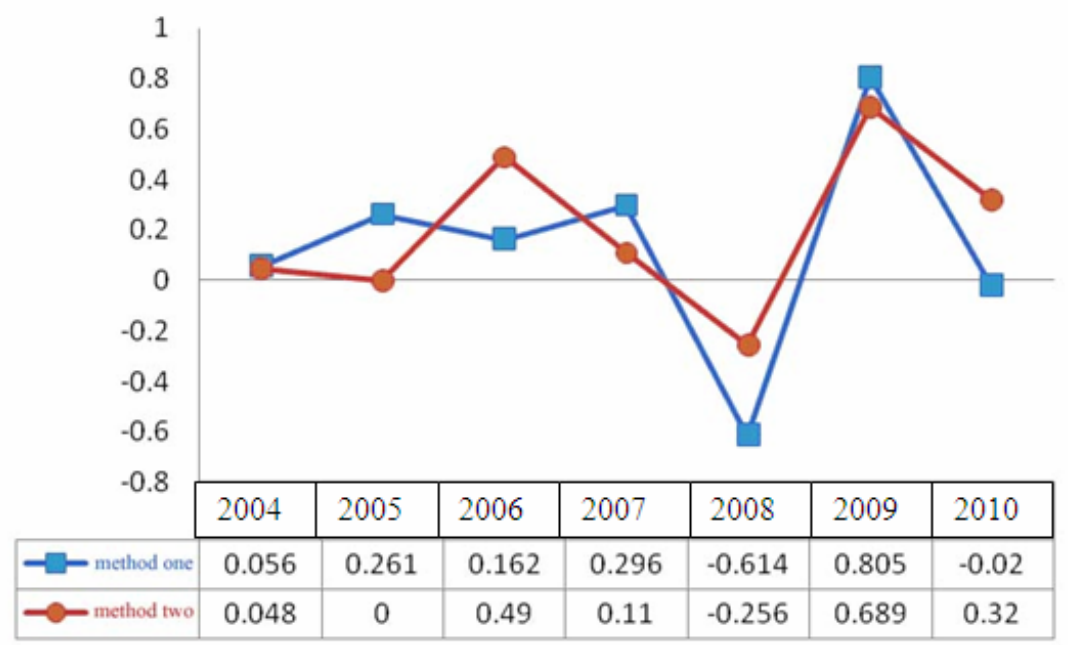

Figure 2. Increase and reduction of the earning conservatism in each portfolio 
As can be seen in both methods (Basu and Ball \& Shivakumar) there is not any relationship between earning conservatism and the ratio of market value to book value also there is not earning conservatism in all portfolios and tested periods, so according to two methods all hypotheses are rejected. The present investigation concluded that there is not any significant relationship between earning conservatism and the ratio of market value to book value that results is similar to Salehi, et al., 2011 results or Salehi and Ghorbani, 2011b.

According to the survey results, it can say that there is not any relationship between the earning conservatism and the ratio of market value to book value. Also there is not earning conservatism in all portfolios and tested periods. It is recommended that users of financial statements and the analysis who try to predict the future profits by current profits, be aware of research results because there may be notion that companies accepted in Tehran stock exchange with lower market value to book value ration have higher earning conservatism as the overseas researches, but according to the current research this is not true for the affiliated companies in Tehran stock exchange.

КОМПАРАТИВНА СТУДИЈА КОНЗЕРВАТИЗМА ЗАСНОВАНА НА БАСУ, БАЛ И ШИВАКУМАРОВОМ МЕТОДУ

\section{Bizhan Abedini and Mahdi Salehi ${ }^{b}$}

\section{Извод}

Представљено истраживање за циљ има анализу односа конзерватизма профита и удела тржишне вредности компанија у Ирану. При анализи је теоријска тржишна вредност прорачуаната преко Басу, Бал и Шивакумаровог метода. Као узорак за истраживање употребљени су подаци, доступни за 155 компаније на берзи хартија од вредности у Техерану. Истраживање је обављено у периоду 2004-2010. година. Конзерватизам профита је мерен преко наведених метода, детаљно описаних у тексту. На основу калкулација, и употребе регресионе анализе, добијени резултати указују да нема значајне повезаности између конзерватизма профита и удела тржишне вредности.

Кључне речи: Конзерватизам профита, удео тржишне вредности, Басу, Бал и Шивакумар метод

\section{References}

Ahmed, A.S., Billings, B.K., Morton, R.M., \& Stanford-Harris, M. (2002). The role of accounting conservatism in mitigating bondholder-shareholder conflicts over dividend policy and in reducing debt costs. The Accounting Review, 77(4): 867890.

Ahmed, A.S., \& Scott, D. (2007). Accounting conservatism and board of director characteristics: An empirical analysis.Journal of Accounting and Economics, 43(2-3): 411-437.

Bainmhahd, B, (2006). Representation and presentation of template to measure accounting conservatism, PhD theses, Islamic Azad university, science and Research, Iran.

Ball, R., \& Shivakumar, L. (2005). Earnings quality in U.K. private firms: comparative loss recognition timeliness. 
Journal of Accounting and Economics, 39(1): 83-128.

Basu, S. (1997). The conservatism principle and the asymmetric timelines of earnings. Journal of Accounting and Economics, 24(1): 3-37.

Beaver, W., \& Ryan, S. (2000). Biases and lags in book value and their effects on the ability of the book-to-market ratio to predict book return on equity. Journal of Accounting Research, 38: 127-148.

Bliss, J.H. (1924). Management through accounts. New York, NY: The Ronald Press Co.

Givoly, D., \& Hayn, G. (2000). On the asymmetric recognition of good and bad news in France, Germany and the United Kingdom. Journal of Business Finance and Accounting, 28: 1285-1331.

Moradi, M., \& Salehi, M. (2011). Evaluating the Investors' Overreaction to Financial Measures: Some Evidence of Tehran Stock Exchange. International Journal of Academic Research, 3(2): 921929.

Mozafar, K. (2009). Estimation and empirical properties of a firm-year measure of accounting conservatism, Working Paper Series, Massachusetts Institute of Technology (MIT).

Namazi, M., \& Salehi, M. (2010). The Role of Inflation in Financial Repression: Evidence of Iran. World Applied Sciences Journal, 11(6): 653-661.

Penman, S.H., \& Zhang, X. (2002). Accounting conservatism, quality of earnings, and stock returns. The Accounting Review, 77(2): 237-264.

Rezazadeh, J. (2002). Relationship between culture and accounting values (conservatism and secrecy) thesis, Allameh Tabatabai University, Iran.

Sadidi, M. (2008). The effect of accounting conservatism on earning quality and stock returns. Thesis, Allameh Tbatabai University, Iran.

Salehi, M., \& Ghorbani, B. (2011). An Investigation of Relationship between Earnings Conservatism and Price to Book Ratio Based on Basu's Method. International Journal of Business and Development Studies, 3(1): 29-40.

Salehi, M., \& Ghorbani, B. (2011b). A Study of Using Financial and Non-Financial Criteria in Evaluating Performance: Some Evidence of Iran. Serbian Journal of Management, 6(1): 97-108.

Salehi, M., Ghorbani, B., \& Jafarian, H. (2011). An Investigation of Relationship between Earnings Conservatism and Price to Book Ratio: Iranian Evidence. World Applied Sciences Journal, 12(9): 1397-1402.

Sterling, R.R. (1970). The Theory of the Measurement of Enterprise Income. Lawrence, KS: University of Kansas Press. 